DOI: 10.1515/ausp-2015-0046

\title{
Dilemmas of Cultural Mediation: A Case Study of Tourism ${ }^{1}$
}

\author{
Zsuzsanna AJTONY \\ Sapientia Hungarian University of Transylvania (Miercurea Ciuc, Romania) \\ Department of Humanities \\ ajtonyzsuzsa@yahoo.com
}

\begin{abstract}
Travelling implies the encounter and, in certain cases, the clash of cultures. By interpreting translation as a means of transfer between languages and cultures, the present study looks into the different views on translating culture-specific realia. Through a close analysis of texts with the purpose of informing foreign tourists it offers ways of how to carry out this mediation. The study calls for further research into closely related issues, such as the translator's cultural awareness of and sensitivity to similarity and difference, identity and alterity in culture.
\end{abstract}

Keywords: culture, realia, mediation, tourism, travel, pragmatic equivalence

\section{Introduction}

This paper addresses the topic of the conference Homo viator the travelling man, man on its way) in two, quite related senses: through both a literal and a metaphoric interpretation of the term "travelling". The literal interpretation of the word is close connection with my topic of analysis, i.e. tourism. OED defines the word "tourism" as "the commercial organization and operation of holidays and visits to places of interest", ${ }^{2}$ "the practice of travelling for pleasure, especially on one's holiday" (Oxford Advanced Dictionary), "the activity of travelling to a place for pleasure". ${ }^{3}$ Implicitly, the term also refers to a movement from a known place to an unknown place, which implies a certain degree of anxiety.

My other approach to the concept of "travelling" to be addressed in this article is the metaphorical interpretation of the term, i.e. translation interpreted

1 This study has been conducted within the research project entitled "Travelling and Cognition" supported by the Institute of Research Programmes of Sapientia Hungarian University of Transylvania.

2 http://www.oxforddictionaries.com/definition/english/tourism

3 http://www.merriam-webster.com/dictionary/tourism 
as travelling, as mediation between two cultures. In Translation Studies this mediation is understood as a constant movement between the Source Culture and the Target Culture (see Bassnett 2011: 77-85). The competence of translators involves not only linguistic skills, but also cultural awareness and anthropological knowledge of the target language speakers and society with special regard to their cultural sensitivities.

\section{Cultural relativism, stereotypes, cultural sensitivity}

The need to be extremely careful about rendering culture specific items from a Source Language (SL) into a Target Language (TL) is especially true of translations made for purposes of tourism (travel brochures, guide books, etc.), which also combine the two approaches to travelling mentioned above. In such cases a competent translator is required to take into account the dangers and problems involved in cultural and linguistic ethnocentrism. The term is related to the principle of "cultural relativism", according to which any individual's beliefs and activities should be understood by others in terms of that individual's own culture. The principle of ethnocentrism entails that individuals judge another culture only by the values and standards of their own culture, i.e. viewing things in a way in which their own group is the centre of everything, and all the others are scaled and rated with reference to this (Sumner 1906: 13, quoted in Leerssen 2007: 323). In other words, cultural ethnocentrism means the absence of cultural relativism. "Ethnocentrism means measuring other cultures by the standards and patterns of one's own culture; this means that the value of normalcy is predicated on one's domestic experiences, while other cultures are seen in their deviancy from that domestic norm, as non-normal, anomalous or abnormal." (Leerssen 2007: ibid.)

Both cultural and linguistic ethnocentrism is heavily tainted with national or ethnic stereotypes. The literature on the subject (Macrae et al. 1996, Jenkins 1996, Hilton \& von Hippel 1996, Augoustinos et al. 2006, Oişteanu 2009) demonstrates how stereotypes may be harmful (they may lead to negative attitudes or prejudices), but they may also enhance cognition, helping individuals to get acquainted with the world around them much more easily and providing them with wellprepared, preconceived ideas and thoughts. Stereotypes may prove to be useful if they are applied in a conscious way; if they are descriptive (not prescriptive or evaluative); if they offer a thorough and precise characterization; if the individual is flexible enough to modify his/her views about the given cultural item or ethnic group relying on his/her observation and experience.

Consequently, the translator is responsible for the correct mediation of a text from the Source Culture to the Target Culture, and should avoid ethnocentrism, keeping the golden mean between foreignization (source-culture orientation) and 
domestication (target-culture orientation) (see Palaposki 2011). In this context, probably the best way is to transfer the characteristics of a foreign culture into the recipient environment by serving one purpose only: to overcome cultural barriers.

According to Shuttleworth and Cowie (1997: 35), cultural translation refers "to any translation which is sensitive to cultural as well as to linguistic factors". The translator, as a cultural mediator, needs to be aware that his own cultural background will influence - one way or another - his/her way of perceiving the world and rendering it in the target language. In order to play the role of a mediator effectively, the translator is supposed to be flexible enough and develop a high degree of cultural sensitivity in order to overcome certain influences of his/her own culture.

There is another danger that plagues translators when dealing with culturespecific items: they are required to be culturally sensitive, i.e. to be conscious of cultural similarities and differences as well as their effect on values, learning and behaviour. (Stafford et al. 1997) In order to be sensitive to other people's cultural and behavioural values, one must not ignore differences in thought patterns, and in values, norms and beliefs. Learning about cultural differences may lead to a greater understanding, and translators should be willing to adapt their communication and behaviours to be compatible with another's cultural norms, as well as to be open to learn traditions and characteristics of different cultures. (Stafford et al. 1997)

\section{Translation of realia}

One of the most debatable issues raised in translation studies is the category of realia (also mentioned as culture-specific terms, culture-bound problems, extralinguistic cultural references). The term realia is a Latin word meaning "the real thing”, and in translation studies, it is used to refer to concepts which are found in a particular source culture but do not occur in a given target culture (Leppihalme 2011: 126). As mentioned above, they are described as extralinguistic terms that refer to the surrounding physical and sociocultural reality, of the "external" language (as opposed to intralinguistic translation problems, which arise from differences between source and target language systems and language usage) (Nedergaard-Larsen 1993: 238, note 1, quoted in: Leppihalme 2011: 126).

Research has provided several typologies of realia, but due to their wide variety, an exhaustive classification is not feasible (e.g. Klaudy 1997: 60-65); Nedergaard-Larsen 1993, Gambier 2007). According to Palumbo (2009), there are various techniques employed in the translation of culture-bound elements. The choice of one technique or another depends on whether the target audience is "already familiar with the term or concept", or whether it is possible to "find 
functional equivalents in the TL, i.e. terms that refer to analogous concepts in the TL culture" (Palumbo 2009: 33). Some terms are borrowed (e.g. samovar, transliterated from Russian), some are translated by calque (i.e. loan translation, e.g. the Milky Way translated from the Latin via lactea). A functional equivalent may also be provided if there are no similar terms in the TL culture (e.g. the Japanese genkan, which is a special room to take off one's shoes, in which case a solution would be to translate this term into Hungarian as elószoba (i.e. anteroom, which might serve the same purpose as in the SL). Another technique is when a SL item is retained and a short explanation is added (e.g. the name of the English newspapers The Guardian, translated into Hungarian as "a Guardian brit napilap” ('The Guardian, the British daily newspaper').

In this study, I apply the Nedergaard-Larsen typology (1993: 211), which presents four main categories of extralinguistic culture-bound problems: (1) geography, (2) history, (3) society, (4) culture, with their own subdivisions. Culture-bound items related to the topic of tourism belong to the subgroup of realia of everyday life, including items like (a) foods and drinks, (b) pieces of clothing, (c) places of living and (d) means of transport. From among these, I have selected the group of foods and drinks and geographic names, the translation of which frequently poses a potential problem for translators (see Chesterman 1997: 89-93).

In order to solve such problems, translators resort to different strategies. These translation strategies have been categorized by research (see, for example, Florin 1993, Nedergaard-Larsen 1993, Leppihalme 2001, Pedersen 2007). "A translation strategy is a potentially conscious procedure for the solution of a problem which an individual is faced with when translating a text segment from one language into another" (Lörscher 1991: 76, quoted in Kylä-Harakka 2008). A translation problem elicits potentially conscious behaviour in problematic situations. As such, the strategies that translators resort to are determined by different conditions. There are several factors determining the choice of one or the other strategy, appearing mostly as a "macro-level aspect of the translation product: the cultural, literary and linguistic profile of the text [...], as well as the translation situation, the attitudes and even the ideology of the translator and the target culture" (Leppihalme 2011: 128).

The latter factors may play an important part in translating culture-specific items related to tourism (especially geographical names) in Eastern Europe, for instance, the Carpathian Basin; due to the border shifts brought about by history, toponyms were changed into the national languages of each presentday country (e.g. the original Hungarian geographical names were replaced by Serbian, Slovak, Romanian, Ukrainian toponyms, which makes their translation into English problematic). Translators have to be sensitive to the socio-cultural and historical context of the region when touching upon such issues, otherwise serious blunders might occur. In such cases each individual country's linguistic 
rules need to be observed, i.e. the toponyms in the official language of the country will be used in an English translation.

Translation strategies of realia includes: direct transfer of the SL word, calque (mirror translation), different types of approximation (e.g. the use of TL superordinate words for SL hyponyms. Leppihalme (2001) distinguishes seven strategies:

(1) direct transfer of the ST word (personal and geographical names are usually transferred directly; some cultures have conventional assimilated or translated forms (Aristotle);

(2) calque (word for word translation, "mirror translation");

(3) cultural adaptation (cultural analogue is substituted for an original realia);

(4) surperordinate term replacing a subcategory (generalization);

(5) explicitation (implicit elements of the realia made explicit in the text);

(6) addition of a text-external (paratextual) explanation (as a footnote, glossary);

(7) omission of the realia altogether.

In the search for a suitable rendering of the source text, the choice of the right strategy mostly depends on the goal-orientedness of the translation. This means that translations are made to fulfil certain purposes and/or at the request of a commissioner. In our case, the translation of a text for tourism purposes serves the interest of potential future travellers to the region and, as such, they have to be as precise, clear, understandable and as welcoming as possible in order to attract future visitors. In such cases, periphrases or explanatory insertion are preferable. However, if the same realia appears in a literary work, without any particular role (e.g., if it is of no particular importance what specific food or drink the character in the story eats or drinks), the translator may employ omission or generalization.

\section{Translating tourism-related terms - toponyms and cuisine}

In this study I examine some problematic situations in which the translation of realia in texts related to tourism poses serious dilemmas even for an experienced and competent translator. The examples to be discussed below have been selected from my experience of translating travel-related texts, travel brochures, from Hungarian into English and vice versa. In this paper special attention is given to place names and culture-specific items related to Hungarian and English gastronomy since to find an acceptable solution can be a really challenging task. First the Hungarian-English, then the EnglishHungarian translations will be considered. 


\section{a. Hungarian-English translations}

A hot topic of the day in Romania in 2015 was the toponym Székelyföld or Szeklerland. The current practice is that it is usually translated from Hungarian into English via direct transfer, i.e. using the original ST variant unchanged in TT (sometimes omitting the accents, dots in spelling). Even so, for an English readership, who do not know much or anything about the region, the name might sound very foreign. Therefore the translator may resort to adding extra information to the toponym, explaining what that is, where it is situated, who its inhabitants are, etc. Therefore a possible translation may be: "Székelyföld (Szeklerland), a historic and ethnographic area in Romania, inhabited mainly by Hungarians and Romanians."

Another option would be to retain the name of the ethnic group (Szekely) and only translate the second part of the compound as a meaningful element (föld - land). In such cases the result is the quite frequently occurring Szekelyland, sometimes also spelt as Szekely land).

As with almost all realia, the translation (mainly by the direct transfer of the term into the TL), does not have the same emotional value for the TL reader as for an inhabitant of the region. Currently, it is also filled with ideological and political connotations, which also adds to the dilemma a translator has to face.

Another set of culture-bound lexical items difficult to translate are such food names which contain the proper name of a historical figure in Hungarian history and culture. Two typical examples are Rákóczi túrós ('baked meringue cheese cake' or 'Hungarian curd cheese square Rákóczi-style' or simply 'Rákóczi cheese cake') and Kossuth kifli (also known as "half moons"). In order to honour the memory of two prominent historical figures of Hungarian history, both desserts were named after them (Ferenc Rákóczi II (1676-1735) was leader of the Hungarian uprising against the Habsburgs in 1703-1711; Lajos Kossuth (1802-1894) was a political reformer who inspired and led Hungary's struggle for independence from Austria in 1848-49). ${ }^{6}$ However, the question arises: how the translator should deal with these when rendering them in English. As the above mentioned translations suggest, both English translations of Rákóczi túrós employ the strategy of explicitation: one of the options is to enlist the major ingredients (meringue and sweet cheese) and the method of preparation (bake) of the cake; the second name also contains the major ingredient of the cake (cheese), which also appears in the Hungarian source variant, but it also emphasises the "nationality" of the dessert. On the other hand, in the case of Kossuth kifli, cultural adaptation is applied by employing a similar analogue existing in English ("half moon"), a term that refers to the shape of the cake.

4 https://en.wikipedia.org/wiki/Székely_Land

5 http://www.britannica.com/EBchecked/topic/490227/Ferenc-Rakoczi-II

6 http://www.britannica.com/EBchecked/topic/322773/Lajos-Kossuth 
The traditional dessert of the Szekelys, called 'kürtőskalács' (sometimes transliterated as kurtosh kalach) can also pose problems. Recently, this special treat has become a popular marker of cultural identity, therefore if the region wants to market its gastronomy abroad, its English translation should also try to cover all the information contained in the SL variant. For those who are not familiar with the term, it can be defined as a spit cake (..) specific to Hungarianspeaking regions of Romania, predominantly the Szekelyland. Kürtóskalács is made from sweet yeast (raised dough), of which a strip is spun and then wrapped around a truncated cone-shaped rotating device, a baking spit, and rolled in granulated sugar. It is roasted over charcoal while basted with melted butter, until its surface cooks to a golden-brown colour, while the sugar stuck on it forms a shiny, crispy crust. The Hungarian etymology of the word links the shape of this dessert to a duct connecting an oven to the chimney. The name itself is a compound noun both elements of which are meaningful (kürtó - duct, chimney; kalács - cake, scone), a possible translation is 'chimney cake'. This term is used by several sites in English, including one of the best-known travel-related sites, www.tripadvisor.com, on how to find this delicacy in London.

However, I have encountered several other variants as well. Below some are listed:

horn cake - This name comes from the misinterpretation and misspelling of the name as kürtöskalács. (with a short ö). In this case we are dealing with the literal translation of the Hungarian kürt - horn, bugle, cornet;

Szekely cake/Sekler cake - contains generalization, the audience will not know specifically which special dessert this name refers to;

Hungarian twister - where the English translation refers to the nation this treat takes its origin from, again in general terms (not specifying which ethnic Hungarian group the cake is connected with) and to its spiral shape (twist). ${ }^{7}$

A similar problem may occur in the translation of another typical Hungarian dish called vargabéles, which is a baked Hungarian noodle-cake dessert served warm or cold. In certain cases the SL name is detained (direct transfer) (see Radu and Radu 2015), or, beside the SL name, explicitation is employed (e.g. 'sweet cheese and raisin cake'; 'Hungarian noodle pastry'; 'Hungarian strudel or Noodle Pie').

\section{4b. English-Hungarian translations}

English-Hungarian translations of tourism terminology also raise dilemmas. Difficulties frequently arise when we are dealing with SL cultural items not to be found in the TL culture. Within the domain of tourism, there are English culturespecific terms which do not exist in Hungarian.

7 See: http://www.kurtos-kalacs.com/. 
One of the most intriguing terms is pub, an important part of British life. Contracted from public house, the word is mainly used in Britain, referring to "a [sometimes several hundred years old] building, not a club or hotel, where alcohol may be bought and drunk during fixed hours." (Longman Dictionary of English Language and Culture) The concept of pub does not have a continental counterpart, neither does it cover the practices and activities related to a Hungarian kocsma. The Hungarian term often collocates with adjectives like sarki ('from the corner') or falusi ('village'). The only feature that an English pub and a Hungarian kocsma share is that alcoholic drinks are served in both of them. An English pub, however, is much more stylish (not only in its external look but also in its clientele, i.e. it may also be the scene of family gatherings, birthdays, children are also allowed in). Another main difference is that the staple drink in a $p u b$ is beer, although spirits, such as whisky or gin, even cider may also be provided here. Besides, an English pub also serves food, called pub grub (Bart 1998: 196-197). For all these reasons, translators are advised not to translate the English term into kocsma. It is common practice that the original SL term, supplied with the necessary Hungarian endings, if necessary, is retained.

They met at the local pub. ('A helyi pubban találkoztak.')

The King's Arms, The Red Lion, The Rose and The Crown are common pub names. ('A The King's Arms, The Red Lion, The Rose és a The Crown gyakori pub nevek.')

Another term that might pose a serious dilemma for the translator is village green. A typical English feature of the traditional British landscape, it is a grassy area at the heart of a village. It was originally common grassland in the centre of an agricultural settlement, and was used for grazing sheep. Most village greens also have a pond or a stream, originally for watering sheep and cattle. Although nowadays it is actually a recreation park for the local community, its name has been retained. English people often think of a game of cricket on the village green in the summer as being a very traditional English scene. As this concept does not exist in Hungarian culture, the translator needs to find a similar term that covers the issues mentioned above. Although there are hardly any present-day Hungarian villages (not to speak of the more tradition-bound Szekely villages) with parks in its centres, the suggested Hungarian translation would be park ('park').

Similar to traditional Hungarian meals mentioned above, the names of traditional English dishes are usually transferred directly from the SL into Hungarian as TL, sometimes accompanied with their short description. Such a dish is Yorkshire pudding, which is light batter, baked, traditionally accompanying roast beef, and often shaped like a bowl, holding some of the gravy. Similarly, Lancashire hot-pot also contains a toponym and a translatable compound ('forró edény'), which will 
not be translated, but taken over via direct transfer. A similar term is Shepherd's pie, defined as cooked minced lamb, placed in a deep baking dish, covered with mashed potatoes and browned in the oven. Although all these names could be translated word for word, it is common practice to retain the SL variant.

However, there are other, less common names of dishes, like devils on horseback, i.e. prunes served on a slice of toast as a savoury, whose literal translation is provided ('ördögök lóháton'), or angels on horseback, i.e. oysters served on a slice of toast as a savoury, whose literal translation might be 'angyalok lóháton'. In these cases my suggested translations are aszalt szilva pirítóson and osztriga pirítós ágyon, which are actually short descriptions of these dishes, as the translation of the names would not help the Hungarian audience in identifying them.

Another gastronomic category includes Scottish, Welsh and Irish national dishes in which the names of the different specialties carry an extra flavour difficult to transfer into Hungarian. Like toponyms, these words also possess heavy emotional and connotative meanings. Each one has a story of its own that the Hungarian readers will never be able to fully understand unless they take the trouble to look deeper into the background of these names. The translator's only choice is to take over these special national culture-related terms and apply the strategy of explicitation, i.e. describe the main ingredients and/or the way of preparing them.

Thus, for instance, haggis is a Scottish national dish "made from the heart and other organs of a sheep cut up and boiled inside a skin made from the sheep's stomach. Haggis it typically eaten with boiled turnips and potatoes, known in Scotland as 'neeps and tatties'”. (Longman Dictionary of English Language and Culture) It is the typical ingredient of Burns' Night celebrations, the birthday of the Scottish national poet Robert Burns. Naturally, all this information cannot be included into the Hungarian translation of haggis, therefore the translator may simply resort to the original term, completed with some implicit information about it (see above) made explicit:

haggis, birkagyomorba töltött, foott, darált birkabelsôség és zabkása, a skótok nemzeti eledele ('haggis, minced and cooked internal organs of lamb and oatmeal, filled into a lamb's stomach; the national dish of Scotland')

A similar problem may occur in the translation of a Welsh national dish, the Welsh rarebit. The Welsh call it caws pobi, which means baked cheese. Therefore the name (Welsh rabbit) may actually be an ironic English reference to Welsh cuisine, as it is far from being related to rabbit: it is a piece of toast covered with cheese and re-toasted under the grill. In this case the suggested translation would ignore the SL name, and include only the description of the dish: 
Welsh rarebit - pirítós, sajttal megszórva és grillezve ('toast, sprinkled with cheese and grilled').

Irish stew is a celebrated Irish dish, it is a meat-and-vegetable stew usually made with lamb or mutton, but sometimes with beef. A possible translation might be ír pörkölt, i.e. the literal translation of the SL term. However, this solution would not evoke the same association in the Hungarian readership as the SL variant, because the Hungarian pörkölt is mainly identified with juicy dishes with (sweet or hot) paprika, its indispensable ingredient. The Irish stew, however, does not contain this typical Hungarian spice. Therefore the proposed translation avoids the word pörkölt, which is replaced by the more internationally sounding ragu ('ragout'):

Irish stew - bárány- vagy juhhúsból, néha növendékhúsból és zöldségből készült ragu ('ragout made of lamb or sheep, sometimes calf, and vegetables')

A special class of culture-specific terms related to English cuisine is constituted by the names of several fishes, very frequent among English dishes. As Britain is an insular country, it is but natural that sea fish like haddock ('tókehal'), sole ('nyelvhal'), gilt-head bream ('aranydurbincs'), whitebait ('apróhal'), is served regularly in restaurants. The Hungarian public cannot be familiar with such dishes because traditional Hungarian cuisine uses fresh-water fish available in the region (although today, with fast and extensive international transportation, practically any kind of fish is available in supermarkets). Therefore the suggested strategy is that if the name of a specific meal made from fish appears in the SL text where a special kind of fish is mentioned, then the Hungarian equivalent must be provided, no matter whether the Hungarian reader is familiar with it or not.

\section{Conclusion}

The success of any translation depends on the cultural competence of the translator. This particularly applies to the translation of realia, which requires not only the knowledge of the TC, but also the ability to make good decisions in order to select the best possible strategies. The aim is that the TT should have the same or similar effect as the ST. The above examples, taken from the domain of travelling and tourism, shed light on the responsibility the translator has for cultural mediation when transferring features of a foreign culture into the recipient environment, the purpose of which is to overcome the barriers between two cultures, and, ultimately, to enhance both incoming and outgoing travelling and tourism.

Despite the differences between languages, translators can convey all experience and cognition in any language by employing loanwords (e.g. keeping the original 
historical name), calques or by meaning transfer (Jakobson 1966, quoted in Simigné Fenyő 2006: 114). Even the small number of examples presented in this paper show that the strategies most frequently employed are explanatory elements and componential analysis. All this proves that translators often complete the TT with information not present in the ST in order to ensure that the message reaches the TT reader by making the original text more informative, even if the TL text becomes more detailed and longer as a result.

\section{References}

Augoustinos, Martha, Iain Walker, Ngaire Donaghue. 2006. Social Cognition. London: Sage Publications.

Bart, István. 1998. Angol-magyar kulturális szótár. [English-Hungarian Cultural Dictionary.] Budapest: Corvina.

Bassnett, Susan. 2011. The Translator as Cross-Cultural Mediator. In: Malmkjær, Kirsten and Kevin Windle (eds.), The Oxford Handbook of Translation Studies, 77-85. Oxford: Oxford University Press.

Chesterman, Andrew 1997. Memes of Translation. The Spread of Ideas in Translation Theory. Amsterdam: John Benjamins.

Florin, Sider. 1993. Realia in translation. In P. Zlateva (ed.), Translation as Social Action: Russian and Bulgarian Perspectives, 122-128. London: Routledge.

Gambier, Yves. 2007. Doubts and Directions in Translation Studies. Amsterdam/ Philadelphia: John Benjamins.

Hilton, James L. \& von Hippel, William. 1996. Stereotypes. Annual Review of Psychology 47: 237-71.

Hinton, Perry R. 2000. Stereotypes, Cognition and Culture. Hove and New York: Psychology Press.

Jakobson, Roman. 1966. On Linguistic Aspects of Translation. In Brower, Reuben Arthur (ed.), On Translation, 232-239. New York: Oxford University Press.

Jenkins, Richard. 1996. Social Identity. London: Routledge.

Klaudy, Kinga. 1997. Bevezetés a fordítás gyakorlatába. [Introduction into the Practice of Translation.] Budapest: Scholastica.

Kylä-Harakka, Paula. 2008. Crime stories from the country of huopatossu and juhannusruusut - Translation strategies for Finnish cultural realia in the English translations of two of Matti Yrjänä Joensuu's crime novels. Unpublished MA thesis.

Leerssen, Joep. 2007. Ethnocentrism, Eurocentrism. In Beller, Manfred and Joep Leerssen (eds.), Imagology. The Cultural Construction and Literary Representation of National Characters. A Critical Survey, 323-324. Amsterdam: Rodopi. 
Leppihalme, Ritva. 2001. Translation strategies for realia. In Pirjo Kukkonen and Ritva Hartama-Heinonen (eds.), Mission, Vision, Strategies, Values: A Celebration of Translator Training and Translation Studies in Kouvola, 139146. Helsinki: Helsinki University Press.

Leppihalme, Ritva. 2011. Realia. In Gambier, Yves and Luc van Doorslaer (eds.), Handbook of Translation Studies, vol. 2, 126-130. Amsterdam: John Benjamins. Longman Dictionary of English Language and Culture. 2005. Third Edition. Pearson Education Limited.

Lörscher, Wolfgang. 1991. Translation Performance, Translation Process, and Translation Strategies. A Psycholinguistic Investigation. Tübingen: Gunter Narr Verlag.

Macrae, Neil, Charles Stangor, Miles Hewstone (eds.). 1996. Stereotypes and Stereotyping. New York: The Guildford Press.

Nedergaard-Larsen, Birgit. 1993. Culture-bound problems in subtitling. Perspectives: Studies in Translatology 2: 207-241.

Oişteanu, Andrei. 2009. Inventing the Jew: Antisemitic Stereotypes in Romanian and Other Central-East European Cultures. University of Nebraska Press.

Palaposki, Outi. 2011. Domestication and Foreignization. In Gambier, Yves and Luc van Doorslaer (eds.), Handbook of Translation Studies, vol. 2, 40-42. Amsterdam: John Benjamins.

Palumbo, Giuseppe. 2009. Key Terms in Translation Studies. London: Continuum. Pedersen, Jan. 2007. Cultural interchangeability: The effects of substituting cultural references in subtitling. Perspectives: Studies in Translatology 15 (1): 30-48. <http://www.researchgate.net/publication/233213421_Cultural_ Interchangeability_The_Effects_of_Substituting_Cultural_References_in_ Subtitling> (April 21, 2015)

Radu, Gelu, Corina Radu. 2015. Cookbook from Transylvania and other places of the world. Fan Zone SRL.

Shuttleworth, Mark \& Moira Cowie. 1997. Dictionary of Translation Studies. Manchester: St. Jerome.

Simigné Fenyő Sarolta. 2006. A fordítás mint közvetítés. [Translation as Mediation.] Miskolc: Stúdium.

Stafford, Joby Robinson, Bowman, Robert, Ewing, Tod, Hanna, Janice, \& LopezDe Fede, Ana. 1997. Building Cultural Bridges. Bloomington: IN: National Educational Service. 